\begin{tabular}{|l|c|c|c|c|}
\hline $\begin{array}{l}\text { Cuadernos de Investigación Geográfica } \\
\text { Geographical Research Letters }\end{array}$ & 2019 & N $^{\circ} 45(1)$ & pp. 195-217 & eISSN 1697-9540 \\
\hline
\end{tabular}

\title{
LATE HOLOCENE ANTHROPIC DEGRADATION RECORDS IN SEMI-ARID ENVIRONMENTS (NE SPAIN AND NW ARGENTINA)
}

\author{
J.L. PEÑA-MONNÉ ${ }^{1 *}$, M.M.SAMPIETRO-VATTUONE ${ }^{2}$ \\ ${ }^{1}$ Departamento de Geografía y Ordenación del Territorio and Instituto Universitario de Ciencias \\ Ambientales de Aragón, Universidad de Zaragoza, 50009 Zaragoza, Spain. \\ ${ }^{2}$ Laboratorio de Geoarqueología, Universidad Nacional de Tucumán and CONICET, San Miguel de
} Tucumán, Argentina.

\begin{abstract}
Information about Holocene sedimentary records in two semiarid areas in Spain and Argentina was gathered to know the role of the anthropic influence on landscape evolution. In both cases, four aggradational units separated by incision phases have been differentiated. Due to the confluence of anthropic indicators, the HIC subunit (ca. 2.45-ca. $1.5 \mathrm{ka} \mathrm{cal} \mathrm{BP)} \mathrm{in} \mathrm{the} \mathrm{central} \mathrm{sector} \mathrm{of} \mathrm{the}$ Ebro basin (NE Spain), and the H2B subunit (2.45-ca. $0.6 \mathrm{ka}$ cal BP) in the Tafi valley (NW Argentina) are worthy of attention. In both cases, a soil formed around 2.45 cal BP was degraded, because it was the object of intense overexploitation in the Ibero-Roman period in the Ebro valley and Formative period in Tafi valley. The final results of these processes represented transformations so significant that the landscape was unable to recover posteriorly. In highly vulnerable dryland environments, the establishment of adequate criteria to link strong landscape degradative phases with human activity is of high interest to know de older phases of the Anthropocene or Paleoanthropocene.
\end{abstract}

\section{Registros de degradación antrópica durante el Holoceno Superior en ambien- tes semiáridos (NE de España y NW de Argentina)}

RESUMEN. Se han utilizado los datos procedentes de registros sedimentarios holocenos de dos áreas semiáridas en España y Argentina con el objetivo de conocer el papel de la influencia antrópica en la evolución del paisaje. En ambos casos, aunque sea con distinta cronología, se han diferenciado cuatro unidades agradativas separadas por fases de incisión. Por su particular confluencia de indicadores antrópicos destaca la importancia de la subunidad HIC (ca. 2,45-ca. $1,5 \mathrm{ka} \mathrm{cal} \mathrm{BP}$ ) en el sector central de la cuenca del Ebro (NE de España) y de la subunidad H2B (ca. 2,45-ca. 0,6 ka cal BP) en el valle de Tafi (NW Argentina). En las dos zonas hay que destacar la presencia de un suelo formado en torno a $2.45 \mathrm{ka}$ cal BP y que por su especial interés agrario fue objeto de una intensa sobreexplotación en Época Ibero-Romana en el valle del Ebro y durante el Formativo en el valle de Tafi. Los resultados finales de estos procesos generaron 
transformaciones tan importantes en sus respectivos paisajes que no llegaron a recuperarse en fases posteriores. En medios semiáridos de alta fragilidad, el establecimiento de criterios que permitan vincular fases de fuerte degradación ambiental con la actividad humana es de gran importancia para conocer las fases antiguas del Antropoceno o Paleoantropoceno.

Key words: Geoarchaeology, Holocene, erosion, Anthropocene, agrarian cultures.

Palabras clave: Geoarqueología, Holoceno, erosión, Antropoceno, culturas agrarias.

Received: 13 March 2018 Accepted: 7 April 2018

Corresponding author: José Luis Peña Monné, Departamento de Geografía y Ordenación del Territorio e IUCA, Facultad de Filosofía y Letras, 50009 Zaragoza, Spain. E-mail address: jlpena@unizar.es

\section{Introduction}

There is a dominant tendency to place the beginning of the Anthropocene in fairly recent dates, such as the beginning of the Industrial Revolution (second half of the $18^{\text {th }}$ century) (Crutzen and Stoermer, 2000, Steffen et al., 2011, 2015; Foley et al., 2013; Smith and Zeder, 2013) or 1945 (Zalasiewicz et al., 2015; Waters et al., 2016). However, most of the cited authors admit that there was a previous and significant influence of man on the planet - although with less influence and a more local focus. This earlier period is named by Ruddiman and Thomson (2001) as the Early Anthropogenic Era and presents a wide range of possible limits, while Foley et al. (2013) use the term Palaeoanthropocene. The influence of man on the environment or climate begins with the processes of gaining farmland, or when fires started to renew pastures for livestock. These processes bring us to the Neolithic (Ruddiman et al., 2015; Ruddiman, 2017). A major release of methane and carbon into the atmosphere could have started as early as 5000 and 8000 BP (Ruddiman et al., 2008). Other criteria, such as the extinction of megafauna species, would push the limit even further back (Smith and Zeder, 2013) to the Late Pleistocene (Koch and Barnosky, 2006, Dougthy et al., 2010). Possible markers for the start of the Anthopocene era include indicators such as anthrosols that show intervention by man (proposed for ca. 2000 BP by Certini and Scalenghe, 2011) or the earliest colonisation of America (Lightfoot et al., 2013; Lewis and Maslin, 2015). From our point of view, each of the proposed limits corresponds to important stages of human intervention, which although not global in their impact on the Earth, have helped to add weight to the processes that lead to changing landscapes. In many arid and semi-arid environments the marks left by anthropic action on a fragile landscape were so deep that subsequent recovery is impossible. This type of process can be framed within the parameters of the Palaeoanthropocene.

In this article, we analyse the records left by the influence of climate and man in two semi-arid locations: the central sector of the Ebro depression, in NE Spain (Fig. 1a), 
and the Tafi valley in NW Argentina (Fig. 1b). Despite differing topographic, geological, geomorphological, and climatic factors they share a common element: the presence of at least one phase of strong degradation due to anthropic causes during the Holocene. This degradation generated a decisive mutation in their respective landscapes - and had a strong economic and social influence on ancient agrarian cultures. An evolutionary model shows the essential components of this process of degradation in drylands and relates them to the processes described in both study zones. It also proposes the basic criteria that could be used to differentiate anthropic causes in Holocene sedimentary records.

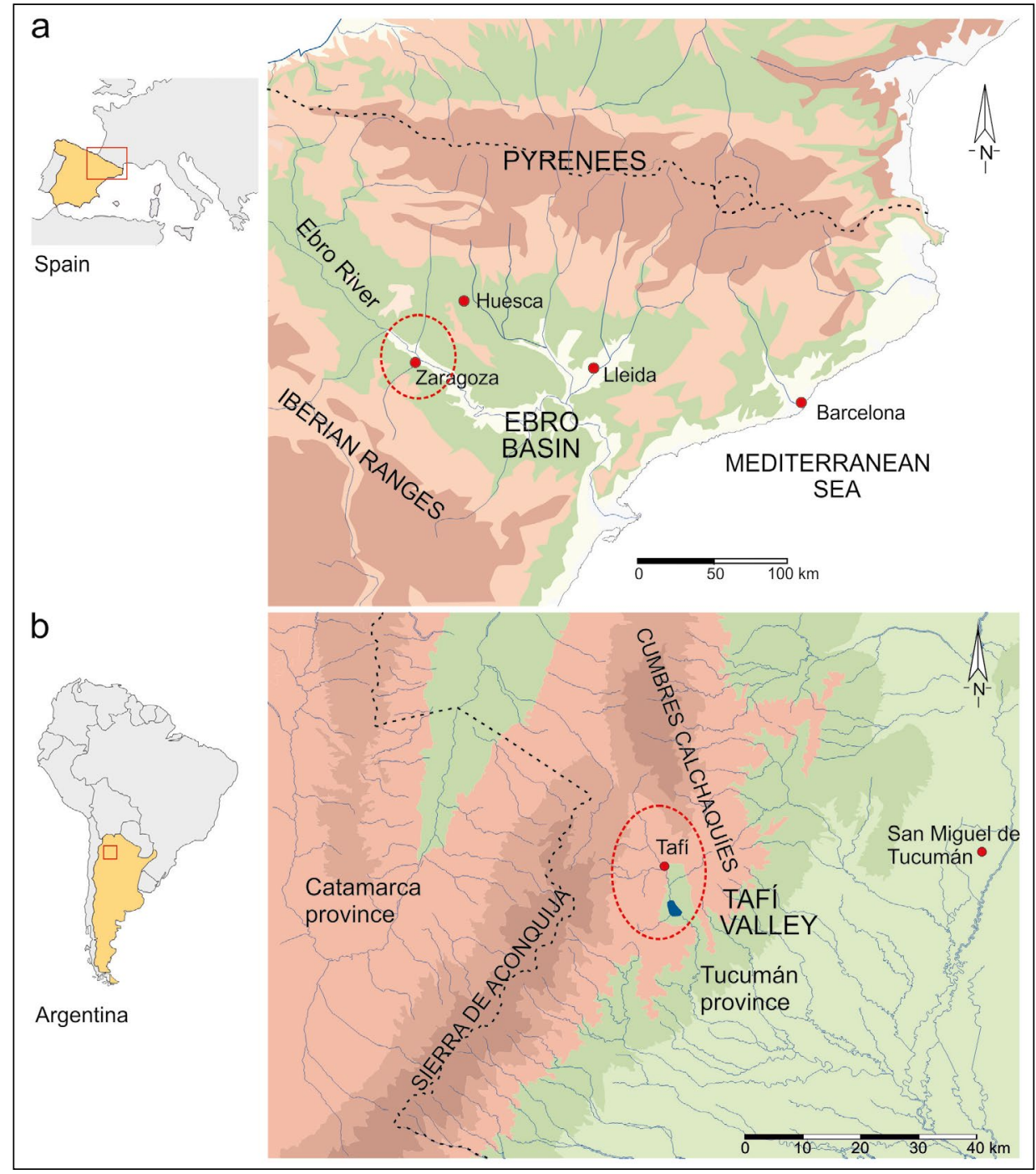

Figure 1. Location maps: a) Central Ebro basin (NE Spain); b) Tafi valley (NW Argentina). 


\section{Regional settings}

The basin of the Ebro River is a tectonic depression located between the Pyrenees and the Iberian Ranges in the NE of Spain (Fig. 1a). It was generated during the alpine orogeny. The basin, converted into an endorheic basin during the Neogene, was filled with continental detrital and evaporitic sediments. In the central sector are accumulations of gypsum and lacustrine limestone, while detrital materials predominate towards the margins. After the opening of the basin to the Mediterranean Sea at the end of the Tertiary, the fluvial network of the Ebro River eroded the Neogene materials. This gave rise to Miocene limestone platforms (muelas) that reach 700-800 $\mathrm{m}$ in height, as well as wide valleys with Pleistocene fluvial terraces and pediments (Gutiérrez Elorza and Peña Monné, 1994; Peña Monné et al., 2002). During the Holocene, the softer materials (gypsum and clays) were subject to intense erosion, which led to badland landscapes with flat-bottomed valleys (vales). In these landscapes are located the main sedimentary records that interest us, especially in a radius of about $25 \mathrm{~km}$ around the city of Zaragoza - at about $300-500 \mathrm{~m}$ altitude. The climate is semiarid continental Mediterranean with an average annual rainfall of between 300 and $600 \mathrm{~mm}$. Rainfall is least plentiful around the city of Zaragoza (314 $\mathrm{mm}$ ) and increases towards the piedmont (Huesca: $587 \mathrm{~mm}$ ). Seasonal temperatures vary considerably: the annual average is around $14.6^{\circ} \mathrm{C}$ (Zaragoza) and oscillates between $6.2^{\circ} \mathrm{C}$ (January) and $24.3^{\circ} \mathrm{C}$ (July). The annual water deficit is estimated at around $1800 \mathrm{~mm}$ per year (Cuadrat, 2004). The vegetation adapts to these very dry conditions (especially in summer) with halophytic steppe formations in the bottom of the central Ebro basin.

The valley of Tafí is located in NW of Argentina and is an intermontane basin in the Sierras Pampeanas (Fig.1b). The depression, whose bottom is located between 1800-2500 $\mathrm{m}$ a.s.l., has a tectonic origin and is bordered by the Cumbres Calchaquíes $(4600 \mathrm{~m})$ to the east, the Sierra de Aconquija $(4600 \mathrm{~m})$ to the west, and Cerro Ñuñorco $(3300 \mathrm{~m})$ to the south. In its central-southern sector, the Loma Pelada $(3000 \mathrm{~m})$ divides the basin into two depressions crossed by the Tafi River and its tributaries. Metamorphic rocks (Precambrian-Lower Cambrian schists and pegmatites - Ruiz Huidobro, 1972) and granitic rocks predominate in the mountains. Most of the Pleistocene materials have been eroded away, or were covered by Holocene sediments; however, the more than $50 \mathrm{~m}$ thick loess accumulations (Kemp et al., 2003) that originally covered most of the valley remain. Lastly, Holocene materials predominate in the bottom and foothills of the Tafi valley and the principal geoarchaeological digs that provide the data for this study took place in their sedimentary sequences. The climate is semi-arid with an average annual rainfall of between 450 and $550 \mathrm{~mm}$ (Tafi del Valle: $476 \mathrm{~mm}$ ), which is concentrated in the summer months (82\%). The Tafi del Valle records an average annual temperature of $13.1^{\circ} \mathrm{C}$. Various climatic and edaphic environments determine the development of various types of vegetation. Alder (Alnus acuminata) and queñoa (Polylepis australis) woodlands are widespread on the slopes and within the ravines, while most areas are grasslands. 


\section{Methodology}

All data were gathered from previous cartographic, field, and laboratory works already published by our team. The information on the stages of aggradation and incision in the two study areas produced during the Holocene has been synthesised graphically. The same time scale has been maintained for the values of aggradation and incision so that both zones can be compared. The respective cultural stages are indicated to show their possible relationship with specific phases. This information enables establishing criteria for human intervention as a triggering factor with respect to natural causes and their application in the two areas analysed. The responses of the territories to both natural and anthropogenic environmental changes are shown in a sequential model.

\section{Results}

\subsection{Holocene records in the central sector of the Ebro basin (Zaragoza, Spain)}

Holocene accumulations in the Ebro valley began to be analysed in the 1970s (Van Zuidam, 1975), although detailed researches with more chronological information started in the 90s (Peña Monné et al., 1993, 1996; Arauzo and Gutierrez, 1994). Genetic interpretations and descriptions of the importance of human actions are more recent (Peña Monné et al., 2000, 2004; Constante et al., 2006, 2009, 2010, 2011; Constante and Peña Monné, 2009; Sancho et al., 2007; Peña Monné et al., 2014, 2018).

Figures $2 \mathrm{a}, 2 \mathrm{~b}$, and $3 \mathrm{a}$ show the stages observed in the accumulations on the slopes and flat bottom valleys (vales) in the centre of the basin (formed on Miocene gypsum and clay materials). These valleys, some of which are currently cultivated, have incisions that expose their sedimentary fillings (Fig. 4a, 4b). The naming of the sedimentary units follows the nomenclature recently established by Peña Monné et al. (2018). Four individual Holocene stages are distinguishable with intermediate incisions ( $\mathrm{H} 1$ to $\mathrm{H} 4$, from oldest to more recent). The oldest dating of Unit $\mathrm{H} 1$ is between 12 and $10 \mathrm{ky}$ cal $\mathrm{BP}$ and the higher layers reach the $4^{\text {th }}$ century AD (Late Roman Epoch).

The thickness of the $\mathrm{H} 1$ unit varies, but it is often between 5 and $10 \mathrm{~m}$, and internally contains all or part of the following subunits. The H1A subunit covers the lower and middle Holocene (between 12-10 ky cal BP and 4.2 ky cal BP) and was described in detail by Pérez-Lambán et al. (2018) at the head of a deep incision in the valley of the Huerva River (La Poza profile). It basically corresponds to fine detrital accumulations with intercalations and channels of gravel and fine gravel, differentiating two stages of stability corresponding to phases of good soil development (s1 and s2 in Figs. 2b and 3a). The total accumulation is $3 \mathrm{~m}$ deep in approximately 6000 years, meaning that the rate is approximately $0.5 \mathrm{~m}$ per 1000 years. 


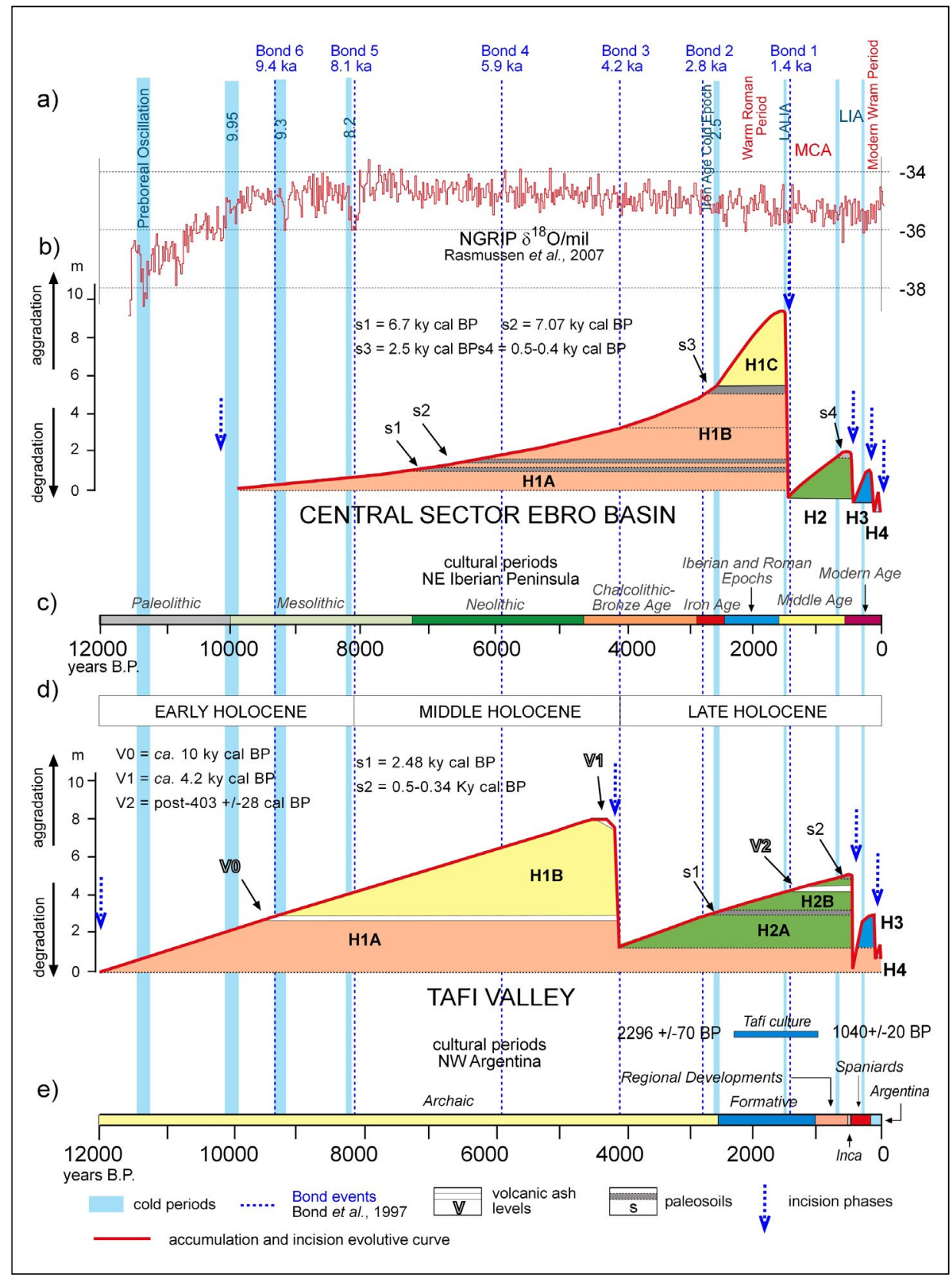

Figure 2. Illustrative draws of the Holocene evolutionary stages; a) Holocene climatic phases (Bond et al., 1997, Rasmussen et al., 2007); b) chronology, thicknesses, and paleosols for units resulting from the stages of aggradation and incision in the central sector of the Ebro basin; c) cultural periods in the NE Iberian Peninsula; d) chronology, thicknesses, paleosols, and levels of volcanic ash resulting from the stages of aggradation and incision in the Tafi valley; e) cultural periods in NW Argentina. 


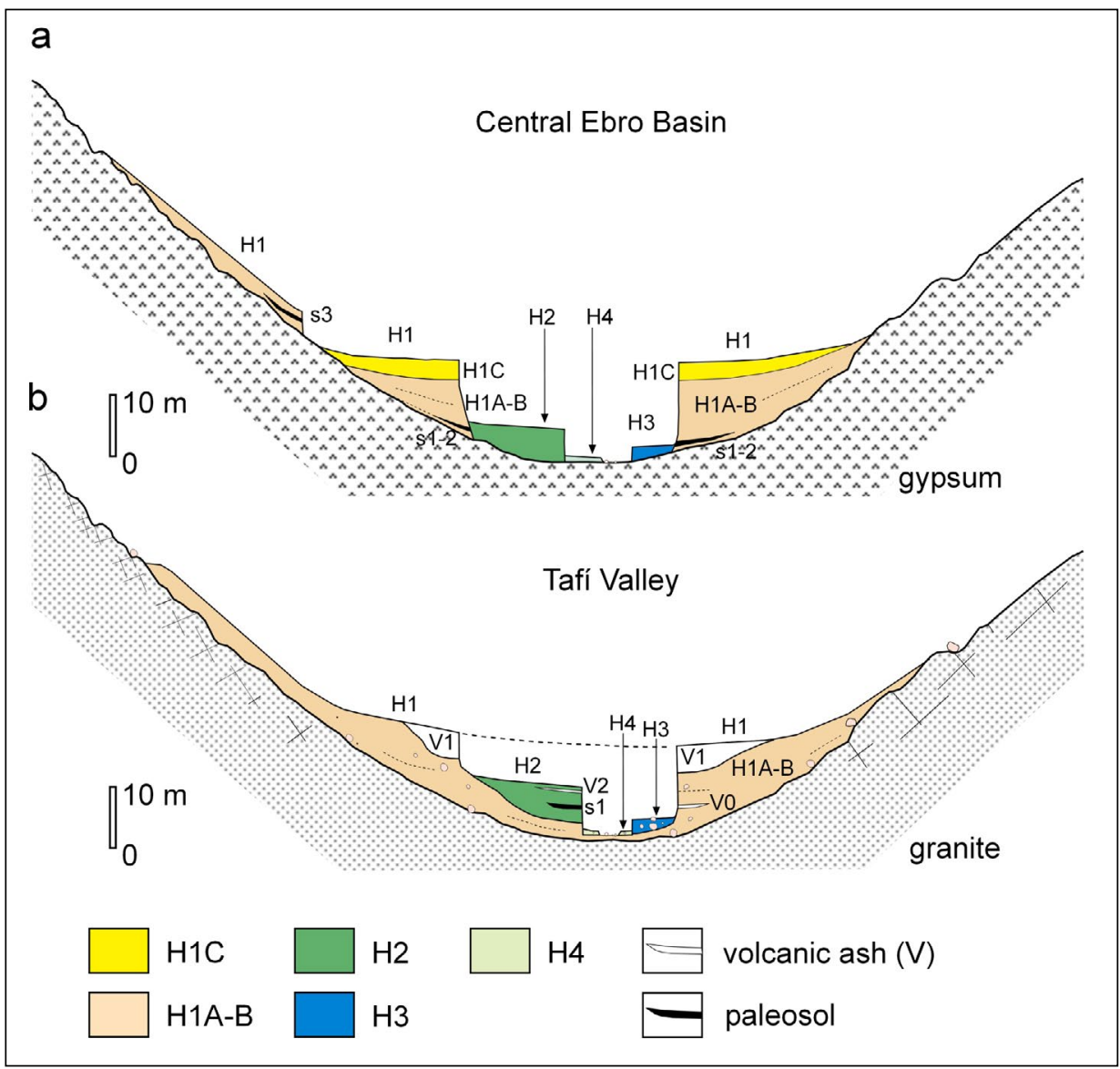

Figure 3. Transversal profiles representative of the central sector of the Ebro basin (a), and the Tafi valley $(b)$, with the position of the Holocene units and other stratigraphical components.

The start of the H1B subunit is well defined by Peña Monné et al. (2011) and PérezLambán et al. (2014) on the slopes of Peña Enroque and in the Huerva River valley - and corresponds to a dry stage (end of the Chalcolithic period) during the Bond 4.2 event (Bond et al., 1997) (Fig. 3a). However, during the H1B subunit (between 4.2 and 2.8 ky cal BP) cold and wet conditions predominated, especially in the final phase (Bond event 2.8 - Bond et al., 1997). At that time, the slopes were well stabilised and soil developed (s3 in Figs. 2b and 3a) and this marked the end of this stage. From the point of view of human occupation (Fig. 2c), the $\mathrm{H} 2$ subunit essentially encompass the end of the Chalcolithic period and the Bronze and Iron ages, that is, a period in which anthropic pressure greatly increases in the region - with many deposits found (Pérez Lambán, 2013). Accumulations grew at an average of $2.6 \mathrm{~m}$ in 1400 years, or a rate of around 1.8 $\mathrm{m}$ per 1000 years. 

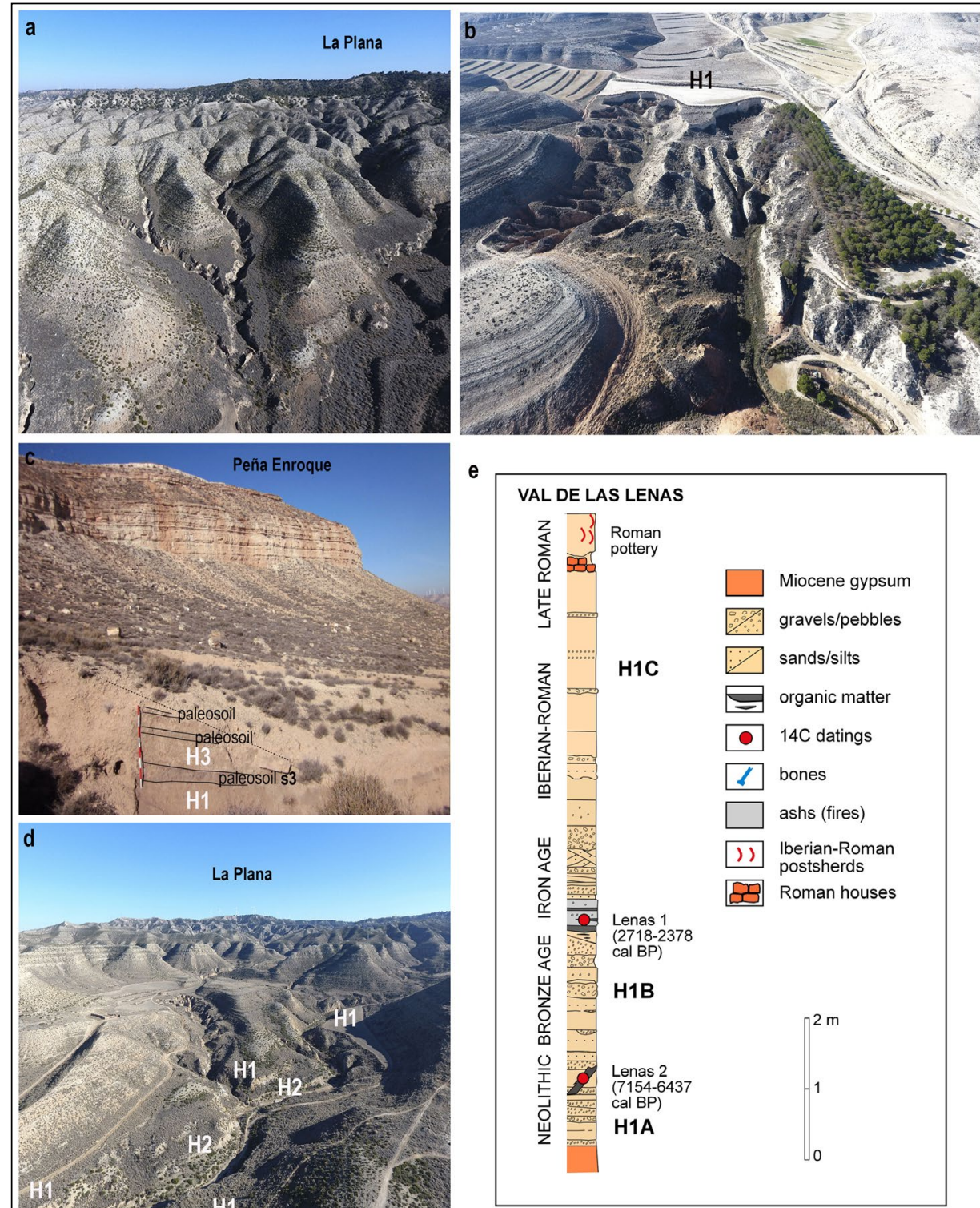

d

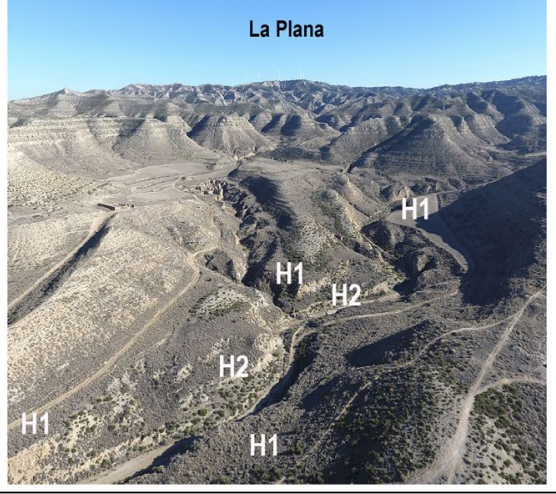

postsherds Roman houses

Figure 4. Holocene accumulations in the central sector of the Ebro basin; a) flat bottom secondary valleys (vales) in Botorrita area; $b$ ) incision in the headwater of the Val de la Magdalena, in the Ginel valley; c) profile on the slopes of Peña Enroque (Muel) with the situation of the main units and paleosoils; d) Holocene aggradative terraces in the Val de la Morera (Huerva River); e) stratigraphic profile of the accumulations of the H1 unit, chronological data in relation with the cultural stages. 
The H1C subunit begins at the end of the Iron Age, so culturally covers the Iberian Epoch (Iron Age 2) and the Roman Epoch until its final stages $\left(4^{\text {th }}-5^{\text {th }}\right.$ centuries AD) (Figs. 2c and 3a). It is a period of maximum demographic growth and a large city Caesaraugusta - expanded in the centre of the valley and served as an administrative centre for the exploitation of the territory. The accumulations in the bottoms of the valley are essentially composed of gypsum silts from the erosion of the slopes (Peña Monné et al., 2004; Constante et al., 2010) with thicknesses of 4-5 m for this period (with an average rate of $4.5 \mathrm{~m}$ per 1000 years - higher in some cases). The soils that had been generated until the Iron Age (during the H1B subunit) were overexploited by arable and pastoral farming. Therefore, it is difficult to find remains of these soils, with exceptions such as those of Peña Enroque, whose paleosol (s3) from this period was conserved by subsequent accumulations (Fig. 4c) (Pérez Lambán et al., 2014).

An incision phase broke the cumulative dynamic of the valleys and the profiles generated by these incisions enable us to recognise the stages (Fig. 4d, 4e). This incision begins after the fourth and fifth centuries $\mathrm{AD}$ and in their interior smaller intermediate cumulative and incision phases were subsequently generated (Figs. 2b, 3a, and 4d). We term these units $\mathrm{H} 2$ and $\mathrm{H} 3$, and they were generated during the Medieval Climatic Anomaly and the Little Ice Age, together with the H4 unit that reaches the $20^{\text {th }}$ century (Peña Monné et al., 2018).

\subsection{Holocene records in the depression of the Tafi valley (Tucumán province, NW Argentina).}

Studies on Holocene accumulations are scarce in Northwest Argentina. The predominance of very active alluvial fans greatly complicates correlations and paleoenvironmental and geoarchaeological reconstructions. In the Tafí valley, the most complete records of the Holocene evolution are those from Sampietro Vattuone (2002, 2010), Peña-Monné et al. (2015), Peña Monné and Sampietro Vattuone (2016), Sampietro Vattuone and Peña Monné (2016, 2018b). Following the same approach as in the Ebro basin, we can distinguish four units (H1 to $\mathrm{H} 4)$ although with a very distinct chronological distribution (Figs. 2d, 3b). These units can appear as stepped terraces in some of the more prominent valleys, such as those in the foothills of Loma Pelada (Fig. 5a). The main accumulation corresponds to $\mathrm{H} 1$, in which two subunits can be differentiated (Figs. 2d and 3b). The lower subunit, H1A, consists of synchronous accumulations of hillsides, valley bottoms, and alluvial fans. While silts and sands predominate on the slopes (and were mostly coming from the erosion of Pleistocene accumulations of loess), the sediments of the valley bottoms are characterised by very bioturbated compact mud. Some locations (in the El Rincón sector) have levels of peat corresponding to frequently flooded areas or wetlands (vegas) alternating with layers of sand (Fig. 5b). This subunit chronologically comprises Final Pleistocene-Early Holocene times (between ca.13.3 and ca. $9.65 \mathrm{ky}$ cal BP) considering the $14 \mathrm{C}$ dates of the peat levels at El Rincón (Garralla, 2002; Garralla et al., 2001) and rodent bones in La Banda (Ortiz and Jayat, 2007). The sub-unit H1A is 2-4 m thick with a layer of volcanic ash (Figs. 2d and 3b) about $20 \mathrm{~cm}$ thick on top, defined as V0 by Sampietro-Vattuone and Peña-Monné (2016), and which 
is approximately $10 \mathrm{ky} \mathrm{cal} \mathrm{BP.} \mathrm{The} \mathrm{H1B} \mathrm{subunit} \mathrm{is} \mathrm{deposited} \mathrm{above} \mathrm{the} \mathrm{V0} \mathrm{tephra} \mathrm{(Fig.}$ $5 \mathrm{~b}$ and $5 \mathrm{c}$ ), and its characteristics are quite different to the previous subunit, as it consists of coarser materials with numerous gravel channels and debris flow deposits from a drier environment and reaches thicknesses of up to 5 to $7 \mathrm{~m}$ (Fig. 5c). Its upper chronological limit is marked by a new layer of tephra (level V1) about 0.4 to $7 \mathrm{~m}$ thick (Figs. 2d, 3b, $5 \mathrm{~b}$, and 5c), which has been dated at around 4.2-3.9 ky cal BP (Sampietro -Vattuone and Peña-Monné, 2016). This tephra generally corresponds with the level dated by Fernández-Turiel et al. $(2012,2013)$ in nearby sectors and the geochemical analyses (Báez et al., 2015) relate it to an eruption of Cerro Blanco volcano in the neighbouring province of Catamarca. Therefore, the $\mathrm{H} 1 \mathrm{~B}$ subunit ranges from $c a .10$ to $c a .4 .2 \mathrm{ky}$ cal BP, meaning part of the Early Holocene and all the Middle Holocene (Fig. 2d). An incision phase establishes the final limit of the $\mathrm{H} 1 \mathrm{unit}$, which is individualized as slopes and fluvial terraces with a final thickness of up to 8 to $9 \mathrm{~m}$ (Fig. 5b). The accumulation rates are around $0.6-1.2 \mathrm{~m}$ per 1000 years for H1A and between $1-1.3 \mathrm{~m}$ per 1000 years for H1B. None of the studied profiles contains remains indicating an anthropic presence during accumulation. Besides, there are not any contemporary occupations known in the valley within the archaeological literature, although in a close valley located to the north of Tafí valley human occupations were dated to $7420 \pm 25$ BP (Martínez et al., 2013).

The $\mathrm{H} 2$ unit is found inside the zones opened by the incision and also covering the set of sediments of $\mathrm{H} 1$ and the V1 tephra, and both superimposed subunits ( $\mathrm{H} 1$ and $\mathrm{H} 2$ ) can often be seen in the profiles of terraces and alluvial fans (Peña Monné and Sampietro Vattuone, 2016) as shown in Figs. 2d and 3b. We can differentiate two sub-levels whose separation is established by the presence of well-developed soils (s1 in Figs. 2d, 3b, and 5d) dated around 2.45 ky cal BP (Sampietro Vattuone, 1999; Sampietro-Vattuone and Peña-Monné, 2016). The H2A subunit therefore encompasses between $c a .4 .2$ and ca. 2.45 cal BP, or the first part of the Late Holocene, and consists of sediments similar to those of the H1B subunit (since much of the material comes from the erosion of the previous level). Its thickness varies greatly -between 2 and $3 \mathrm{~m}-$ and so a cumulative rate between 1.1 and $1.7 \mathrm{~m}$ per 1000 years can be calculated. The H2B subunit begins after the formation of soil s1 (Fig. 2d), which is also contemporary with the s3 soil level described in the Ebro depression (Fig. 2b). This paleosol and the levels above (H2B subunit) (Fig. 5d) contain the remains of ceramics, camelid bones, mortars, etc. in many of the analysed profiles, and even Formative archaeological occupations, which in the Tafí valley correspond to the Tafi Culture whose development occurred between $2296 \pm$ $70 \mathrm{BP}$ and $1040 \pm 20 \mathrm{BP}$ (Fig. 2e). This soil was superficially exposed in some areas and intensively farmed (Roldán, 2014), but in other areas it was covered by the H2B subunit during the Tafi period and later dates, since the most recent dating obtained (La Puerta River) for this stage is 646-535 cal BP at a level that already contains ceramics from the Regional Developments Period (Fig. 5e). Therefore, H2B is between ca. 2.45 and $c a .0 .6$ ky cal BP. Note the presence of another level of volcanic ash (V2) in the higher levels of H2B (Figs. 2d, 3b), whose minimum age has been established by Sampietro Vattuone et al. (2018a) in El Paso (Santa María valley) as later than the $15^{\text {th }}$ and $16^{\text {th }}$ centuries. A provisional calculation of the $\mathrm{H} 2 \mathrm{~B}$ accumulation rate is around 2.5 to $3 \mathrm{~m}$ per 1000 years, and so this unit shows the highest cumulative rate in the Tafi valley. 
The H2B unit ends with an incision phase, which leaves hanging terraces and fans of the $\mathrm{H} 2$ phase. Two other minor cumulative phases $(\mathrm{H} 3$ and $\mathrm{H} 4)$ are always reduced to the interior of the narrow incisions and form two small terraces with little continuity (Figs. 2d, 3b, and 5a).

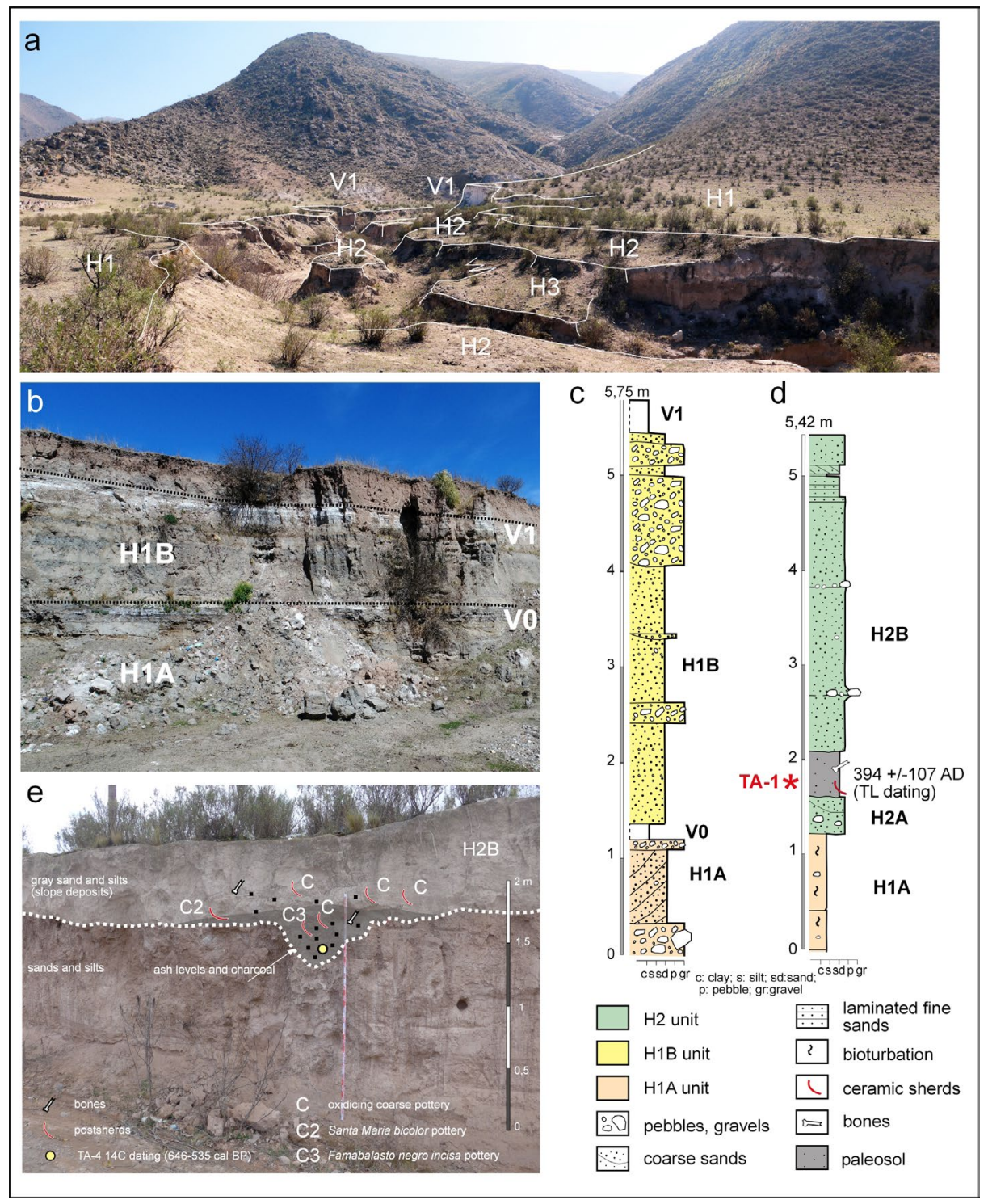

Figure 5. Holocene accumulations in the Tafi valley; a) Holocene terraces and volcanic ashes in a tributary of the Tafi River (Loma Pelada piedmont); b) Holocene units of the El Rincón profile; c) stratigraphic profile of the La Angostura ravine with the two $H 1$ units and interspersed volcanic ash levels (VO and V1); d) stratigraphic profile of the Ojo de Agua Cemetery ravine formed primarily by the unit H2, with s1 paleosol and archaeological remains of the Tafi Culture; e) profile of La Puerta River, with the most recent levels of $\mathrm{H} 2 \mathrm{~B}$ and ceramics from the Regional Development Period. 


\section{Discussion}

Drylands respond quickly to changes that affect their geomorphological stability and even small Holocene climatic fluctuations leave marks on the landscape. In the same way, human interventions can trigger geomorphological processes, as these were periods with increasing anthropic pressures on the natural environment. It is not always possible to distinguish the consequences of both influences, especially as convergences can occur in the trigger mechanisms and resulting processes. It is possible to refer to climaticanthropic influences in the origin of some of the dryland landscapes (Peña Monné et al., 2004; Dearing, 2006; Dotterwich, 2008).

In Fig. 6 an evolutionary model with small climatic fluctuations has been synthesised for drylands occupied by pre-industrial agrarian societies (not corresponding to specific dates or cultures) in an attempt to generalise -although the Prehispanic agrarian periods and Ibero-Roman Era is shown in the final part (Fig. 6h).

The environmental change from sub-humid to semi-arid conditions (Fig. 6a) had major consequences both in natural evolution, without human intervention in the ecosystem (Figs. 6a, and 6c), and in environments with intensive human land use (Figs. 6d, and 6h). In the first case, during this climatic transition, the soils (Fig. 6b) lost their stability and were degraded as the vegetation reduced the protection when it adapted to a drier environment (Fig. 6c). Well-developed soils and a favourable climate often favour a process of stable human occupation, as is the case of sedentary agrarian societies that follow an evolutionary rhythm similar to the environment -with demographic and economic expansion in the most favourable phases (Fig. 6d). This can give rise to the flowering of a culture with well-defined traits (Fig. 6e). However, transition to drier conditions always means less space for farming, economic crises, and food shortages (Fig. 6d). This leads to social crises that affect the structure of the community and produces subsequent cultural and political adjustments (Fig. 6e). In short, such drier conditions lead to a decline in population because of increased mortality, decline in birth, and the possibility of migratory movements. A restart of the semi-arid/sub-humid cycle could lead to a new cultural order, with another period of population expansion and economic growth, but this does not always happen.

From a geomorphological point of view, the process of occupation and population growth has immediate consequences, regardless of any change in climate. The need to obtain land for farming and grazing implies a process of progressive deforestation and changes in land use (Fig. 6f) that also causes a break in the stability of the soil, which will be degraded as the land is used without external protection (Fig. 6g). The vegetation adapts to the degraded soils with species suited to the new conditions and the establishment of secondary successions. This change leads to geomorphological instability and a rapid increase in the erosive processes of all the geomorphological systems (Fig. 6h), and this action translates into a washing away of the finest sediments and organic matter in the soil.

An especially significant aspect of these impacts is the mobilisation of silt: both horizontally by erosion; and vertically by increased flooding in areas of agricultural 
clearings (Homburg and Sandor, 2011; Sandor and Homburg, 2017). The creation of rills and gullies on the slopes - where erosion dominates - causes the transfer of large masses of sediments to valley bottoms and where accumulation becomes the dominant process (Fig. 6h). This dynamic is maximised and accelerated if the process of human occupation and subsequent deterioration are generated just at the same time as the climate becomes drier. The consequences of a highly overexploited area with considerable population pressure are difficult to reverse -and so the degradation becomes permanent.

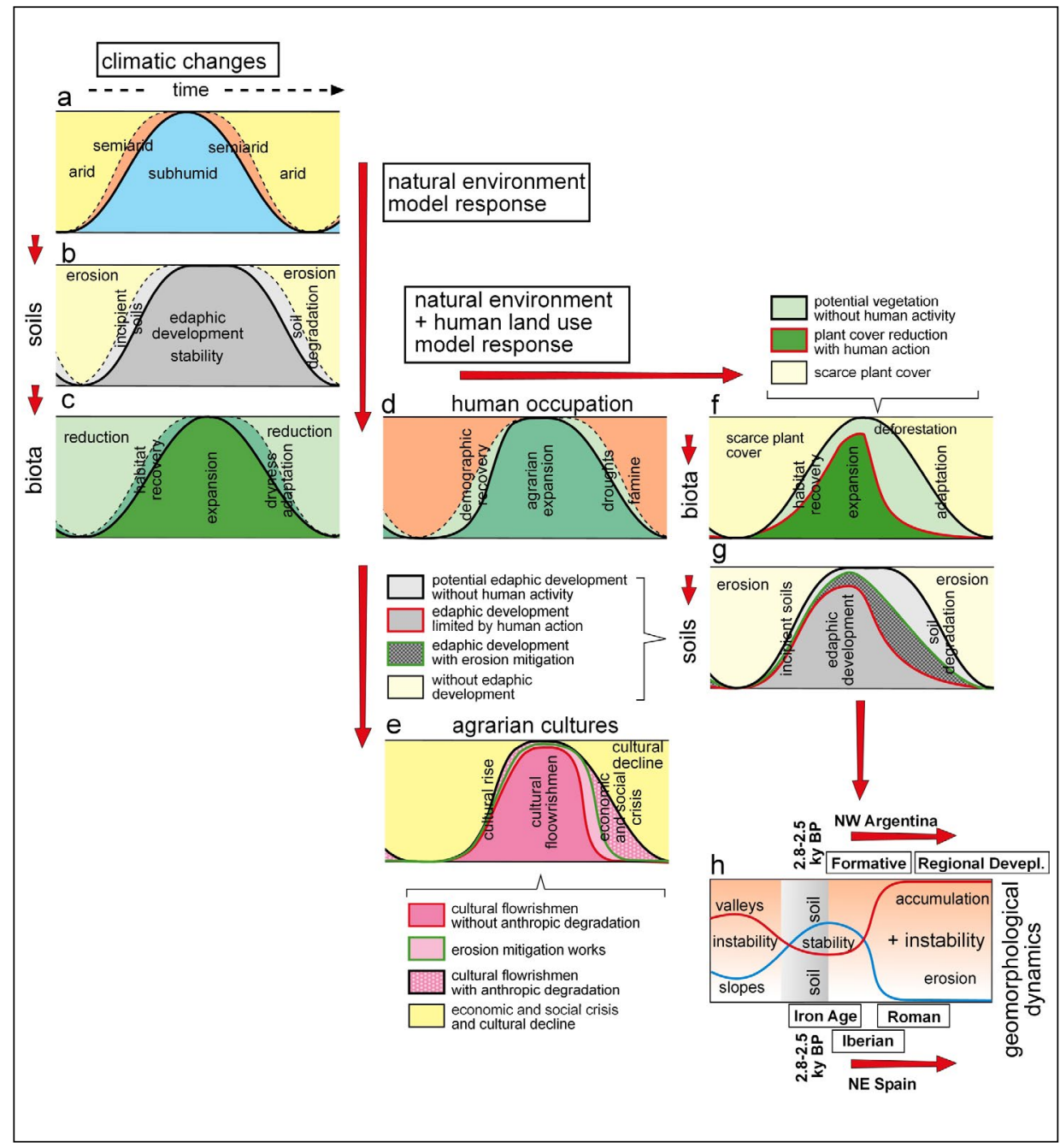

Figure 6. Schematic model of the responses of soils and vegetation in a process of climatic change in semiarid environments; $a$-c) in a natural environment; $d$ - $g$ ) and with the occupation of agrarian cultures; $h$ ) geomorphological response of the process of degradation and its relationship with the influence of land use changes on cultural changes of NE Spain and NW Argentina. 
Of course, there are possible cultural responses -plus the possibility of developing such responses to specific stress situations. Some societies were aware of the problem and devised systems of terraces and platforms to alleviate the erosion of farmland, or implemented complex irrigation systems with ditches and water reservoirs. Another manner of coping with situations of stress linked to environmental degradation and the loss of resources is to establish commercial networks- or raid other groups. This leads to the establishment of fortifications and sophisticated storage systems (Dillehay and Kolata, 2004; Benson and Berry, 2009). In the worst cases, dominant cultures in phases of demographic-economic expansion conquer new territory and then overexploit its resources. In these cases, degradation is maximised since there is not investment in mitigation measurements glance.

At first glance, there are major differences in the Holocene evolution of the two zones described and a comparison of the two graphs in Figs. 2 and 3 reveals the differences. However, there are points in common that are derived from anthropic activity and are the causes of the main processes of landscape degradation - and which fit perfectly into the proposed model. The processes derived from a near 'natural' evolution with little human action, such as the stages H1A, in both cases in the Early Holocene, made no noticeable influence on the landscape. However, from $\mathrm{H} 1 \mathrm{~B}$, although in both cases at different times, there is a significant increase in accumulations in the valley floor and the slopes, with rates of $1.8 \mathrm{~m}$ per 1000 years for the Ebro depression and 1-1.3 m per 1000 years for the Tafi valley. In the former case, this effect occurs in an area of known growth in human occupation (Mesolithic-Neolithic), although preserved remains of occupations from that period in the area are almost non-existent. The same situation of social complexity can be pointed to in NW Argentina, where in this period the domestication of camelids, the raising of livestock, and the transition from a huntergatherer society to the Formative (farming economy) occurred, although there is no reliable data on occupations of this period in the Tafi valley. In both cases, it can be argued that the subsequent degradative action would not have preserved such ancient human settlements in situ, unless fossilised under Holocene sedimentary layers. In the case of the Tafi valley, the H1B accumulation could be the consequence of an intense deforestation process, although in this case there is no evidence for occupants who could generate this action and so any hypothesis aimed at an anthropic genesis remains for the moment unfounded.

The great coincidence in both places is the presence of a soil developed during the same period as a result of a wet and cold climate: the Iron Age Cold Phase ( $8^{\text {th }}$ to $6^{\text {th }}$ centuries BC). The importance of this climatic phase in the evolution of landscapes is evident and seems to have been the basis for a successful development of farming societies (the Celtiberian/Iberian cultures in the NE of the Iberian Peninsula, and the Formative cultures in the NW of Argentina, and specifically, the Tafi Culture in the study area).

In the central sector of the Ebro basin, the soil has been defined by Pérez-Lambán et al. (2014) as Haplic Regosol, with OM contents of 1.5 to 4\%, a C/N ratio of 18 to 30, and a phosphorous content $200-280 \mathrm{mg} / \mathrm{kg}$ (this being the only sector where it is preserved 
intact). In the Tafi valley, a soil of this age has been analysed in 26 farming profiles, with OM levels in the A horizon of 1.37 to $4.5 \%$ (Sampietro Vattuone, 2010; Roldán, 2014). The $2 \mathrm{~A}$ horizon has often disappeared in these soils that have been decapitated by erosion. This soil favoured a significant phase of slope stability in both regions, with a predominance of regularised morphologies. These morphologies reflect wetter and colder paleoenvirontmental characteristics (Sampietro Vattuone, 1999; Peña Monné et al., 1996).

In the central sector of the Ebro basin, major movements of people are recorded from the Bronze Age, and these movements increased in the Iron Age and led to the Celtiberian and Iberian Cultures in the Iron Age 2 (Burillo, 2007). The Roman conquest of this area ended during the $2^{\text {nd }}$ century $\mathrm{BC}$ and the diverse regions of Hispania became tributaries of the Roman Empire by the end of the $1^{\text {st }}$ century (Tovar and Blázquez, 1975). The climate became drier and warmer (Roman Warm Period) and this trend continued throughout the Roman Period, with a climate more favourable to erosion than in previous periods. In addition, the erosive degradation was also favoured during the Roman occupation. The foundation of Colonia Caesar Augusta (ca. 24 BC) (Arce, 1979) along the Ebro River turned the city's surroundings into an area of agricultural and commercial exploitation. Tree-felling finished the last redoubts of vegetation in the area, including areas with steep slopes. The extensive cultivation of cereals, vineyards, and olive together with cattle production became the dominant activities. Exportation to Rome and other regions of the empire using Roman roads and ports facilitated intense commercial exchanges (Blázquez, 1978, 1980; Beltrán Lloris, 1980). As a result, the soils generated during the Bronze and Iron Ages were stripped of protection and began to erode. Huge masses of sediment moved down the slopes along with the runoff water until the gypsum slopes were left bare and unusable. Storms following provoked fires caused identifiable deposits in the sedimentary records of the valleys; layers of ash with fragments of charred tree trunks and branches are often visible, forming highly continued layers, as in the Val de la Morera on the Huerva River where some levels are 15-30 cm thick (Figs. 7a, and 7b) and which have been dated to between the beginnings of the Iberian Period and the Late Roman Period (Peña Monné et al., 2004) (Fig. 4e). The maximum rates of accumulation due to this genesis are found in the subunit H1C (rates of $4.5 \mathrm{~m}$ per 1000 years) and this may be related to the expansion of the Roman agrarian structures (centuriatio) and the population expansion from the 3rd century $\mathrm{AD}$ when large farming villae expanded on the alluvial fans in the territorium around Zaragoza. The accumulations widened the bottom of the valleys, creating new cultivable areas; however, the continuation of their geomorphological dynamics until the $4^{\text {th }}$ and $5^{\text {th }}$ centuries also caused many of the villae (Fig. 7c) and other agrarian structures to disappear under the sediments. Today these remains are only visible in the incisions that cross these zones, which are estimated to have begun to form from the $5^{\text {th }}$ to $6^{\text {th }}$ centuries $\mathrm{AD}$ (Fig. 2b). The incision was not generalized to all valleys, some of them still preserve its plane bottom shape. Dusar et al. (2008), Notebaert and Berger (2014), and Notebaert et al. (2014) show that in different Mediterranean areas an increase in the floodplains sediment deposition rates occurred due to an intense anthropogenic land use, especially during the Hellenistic-Roman Period. 

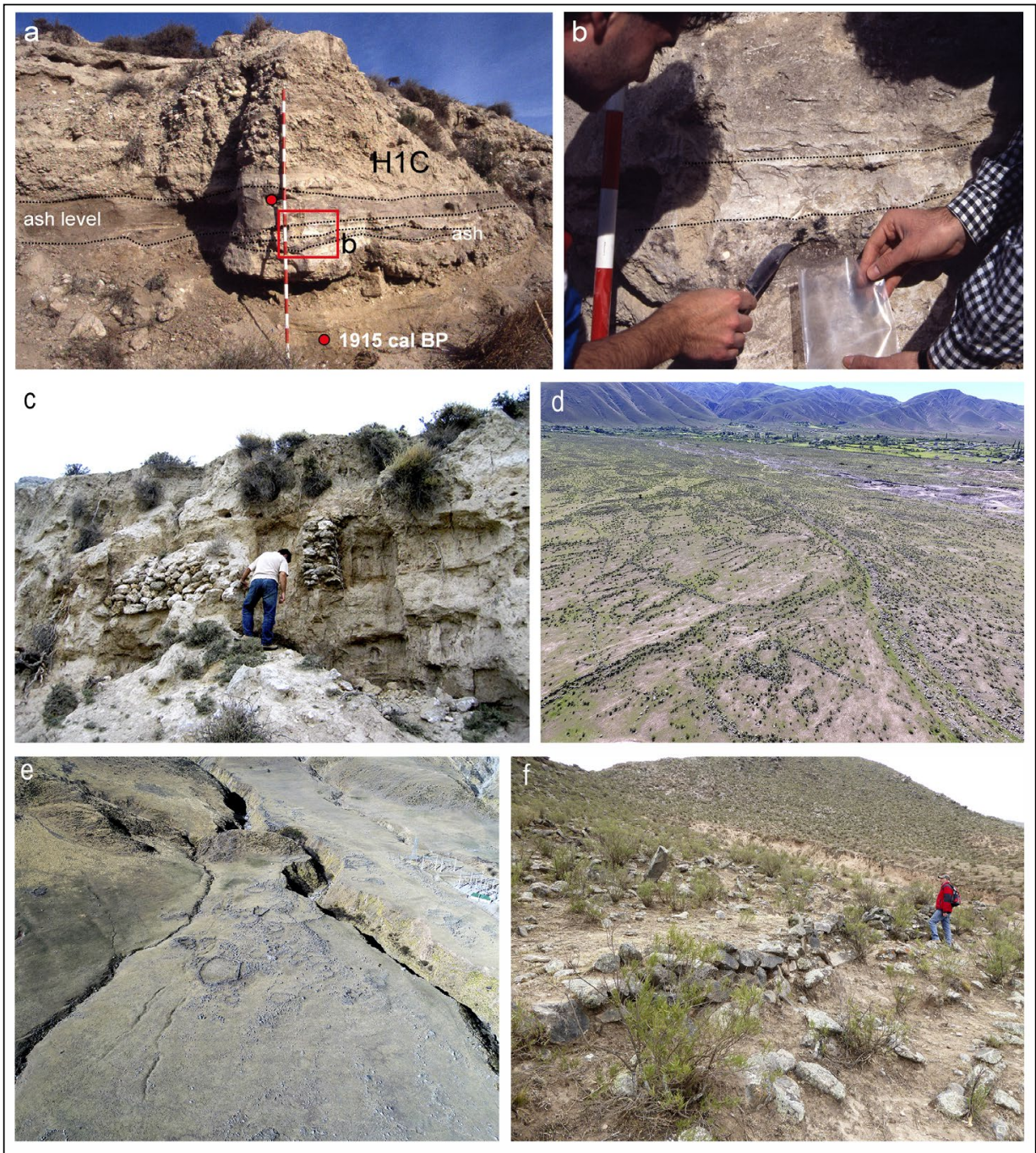

Figure 7. Images of the anthropic influence in the central sector of the Ebro basin: a) stratigraphic profile of $\mathrm{Hl}$ unit in the Val de la Morera; and $b$ ) detail of ash from fires and charcoal levels; $c$ ) Roman house included in HIC in the Val de la Señora (Alfocea). Images of anthropic influence in the Tafi valley: d) structures of houses, corrals, and farm fields in the alluvial fan of La Costa; $e$ ) occupation of the Tafi Culture on the El Bolsón fan; f) eroded remains of terraced farm fields on the slopes of Loma Pelada.

We have established some basic criteria to differentiate distinctive features in the sedimentary records derived from human activities than those triggered by only natural processes:

- registration in the $\mathrm{H} 1 \mathrm{C}$ subunit of the highest accumulation rate (up to $4.5 \mathrm{~m}$ per 1000 years) showing the thicker Holocene sedimentary records. 
- domination of hillside processes over those of longitudinal fluvial drag, which is shown in the predominance of gypsum silts in $\mathrm{H} 1 \mathrm{C}$ due to sheet flood and rill wash processes. This composition contrasts with the gravel accumulations that characterise other Holocene units where fluvial dynamics dominate as a result of climatic influence.

- $\quad$ exclusivity of $\mathrm{H} 1$ fillings, and especially $\mathrm{H} 1 \mathrm{C}$ in the tributary valleys, in such a way that their terraces lack correlative accumulations in the main river. In contrast with the $\mathrm{H} 2$ and $\mathrm{H} 3$ units that have their equivalents on the main river, indicating a much more climatic influence extensive to the entire basin.

- the geomorphological processes of H1 unit altered previous archaeological sites and contemporaneous settlements during its dynamic phase until Late Roman Period. Many of the constructions made in high positions for defensive reasons (Bronze and Iron Ages, Iberian Epoch) have lost many of their elements, sometimes leaving only some defensive traces, such as the large Iberian moats (Peña Monné et al., 2014). In contrast, those settlements in low areas (Mesolithic, Neolithic, Roman) were covered with these deposits at different times (Peña Monné et al., 2014). In both cases, reconstruction is only approachable using geoarchaeological techniques (Peña Monné et al., 2005).

This process of environmental degradation has shaped the current landscape of the area around Zaragoza city. The gypsum lithology dominance of the Miocene substrate favoured the fast erosion processes and impedes the recovery in vegetation cover.

In Tafí valley, as already indicated, our knowledge of the old stages of peopling, which may have been related to unit $\mathrm{H} 1$, is null, and the first known occupation or culture is found during the development of unit $\mathrm{H} 2$ and corresponds to the Tafí Culture. The $\mathrm{H} 2$ unit began to be deposited in an uncertain date of the Late Holocene, after the incision that left the H1 phase individualised, and so deposition was necessarily after $c a .4200 \mathrm{BP}$. This unit has an intermediate soil dating from $c a$. $2.45 \mathrm{BP}$ which marks the beginning of the $\mathrm{H} 2 \mathrm{~B}$ subunit in which the Tafi Culture is settled and whose duration is estimated at between $2296 \pm 70$ BP and $1040 \pm 20$ BP (Sampietro-Vattuone and Peña-Monné, 2016; Sampietro Vattuone et $a l ., 2018 \mathrm{~b})$. The well-preserved remains of these occupations extend through various areas of the valley, and are easily visible as they used large blocks of stone from the alluvial fans to build houses and the walls of their farming terraces (Fig. 7d and 7e). Settlement areas, corrals, and terraced fields even ascend steep slopes (Fig. 7f) up to altitudes of $3000 \mathrm{~m}$ (Sampietro Vattuone, 2010). As in the centre of the Ebro basin, there is much sediment susceptible to erosion, although it mainly comes from the Pleistocene loess, and sands of variable grain-size from the alteration of granitic and metamorphic rocks (grus). The period of occupation corresponds to a sub-humid climatic phase that was transitional before the dryness of around the year $1000 \mathrm{BP}$, as highlighted in the region by Peña-Monné et al. (2015). The driest environment coincided with a human overpopulation, and a consequent overexploitation of the land, which may represent the end of that culture since the latest dates do not exceed $990 \pm 30$ BP (Franco Salvi et al., 2014). The subsequent Pre-Hispanic farming occupations, Regional Development Periods, included in these deposits did not reach an intensity of land use comparable to those of the Formative. 
Many of the criteria described above as indicators of anthropic genesis for the Ebro basin can be applied to the accumulations of the H2B subunit. There are predominantly fine deposits that reach substantial thicknesses and are interspersed with archaeological remains. Human occupation produced a major change in the land-use during the Formative to adapt it to and agropastoral production. The analysed soils show evidence of this overexploitation (Roldán, 2014). In short, the landscape of Tafi valley for the H2B subunit is a consequence of a high level of human intervention that activated erosive processes characteristic of accelerated morphogenesis.

\section{Conclusions}

Drylands reveal very clear responses to the environmental changes of the Holocene, especially when there is also human intervention. Differentiating the mechanisms of anthropogenic genesis from natural mechanisms is complex and requires a detailed analysis of the Holocene sedimentary records, establishing the characteristics and chronological limits of the aggradative units and the intermediate incision stages with maximum precision. Both in the central sector of the Ebro basin and in the Tafi valley, four large aggradative units were identified, with the two oldest units most clearly seen. The existence of a well-developed soil (s1 in Tafí valley; s3 in the Ebro valley) with dates around $2.45 \mathrm{ky}$ cal BP (Iron Age Cold Phase in Europe) supported an important agrarian occupation in both regions, which correspond to the H1C subunit in the Ebro (IberianRoman Epochs) and the H2B subunit in the Pre-Hispanic Agrarian Period (Tafí Culture and Regional Developments Period). The analysis of the Holocene sedimentary records of the two zones enables us to establish different criteria for the anthropic footprint in these stages. These criteria are based on the rates of erosion/accumulation, sedimentary thickness, characteristics and origin of the material, and presence of associated anthropic elements. The changes generated by this action in the landscape in the Iberian-Roman Epochs (Spain) and the Pre-Hispanic Agrarian Period (Argentina) had important consequences that prevented a subsequent natural recovery, so they should be considered as an effect of the Palaeoanthropocene.

\section{Acknowledgements}

This paper was carried out within the scope of the "Primeros Pobladores del Valle del Ebro" project, funded by the Aragón Government and European Regional Development and IUCA (Environmental Sciences Institute of the University of Zaragoza, Spain). Financial support was also received from MINECO/FEDER HAR2015-65620-P Project and PIUNT G629 from Universidad Nacional de Tucumán.

\section{References}

Arauzo, T., Gutiérrez, M. 1994. Evolución de los valles de fondo plano del centro de la Depresión del Ebro. In: J. Arnáez, J.M. García-Ruiz, A. Gómez-Villar (Eds.), Geomorfología en España. III Reunión Nacional de Geomorfología, Logroño, pp. 277-290.

Arce, J. 1979. Caesaraugusta, ciudad romana. Guara Ed., Zaragoza. 
Báez, W., Arnosio, M., Chiodi, A., Ortíz-Yañes, A., Viramonte, J.G., Bustos, E., Giordano, G., López, J.F. 2015. Estratigrafía y evolución del Complejo Volcánico Cerro Blanco, Puna Austral, Argentina. Revista Mejicana de Ciencias Geológicas 32 (1), 29-49.

Beltrán Lloris, M. 1980. El comercio del aceite en el valle del Ebro a finales de la República y comienzos del Imperio. In: J.M. Blázquez (Coord.), Producción y comercio del aceite en la antigüedad. $1^{\circ}$ Congreso Internacional, Madrid, pp. 187-224.

Benson, L.V., Berry, M.S. 2009. Climate change and cultural response in the prehistoric American Southwest. Journal of Southwestern Anthropology and History 75 (1), 87-117. https://doi. org/10.1179/kiv.2009.75.1.005.

Blázquez, J.M. 1978. Historia Económica de la Hispania Romana. Ed. Cristiandad, Madrid.

Blázquez, J.M. 1980. La exportación del aceite hispano en el Imperio Romano. Estado de la cuestión. In: J.M. Blázquez (Coord.), Producción y comercio del aceite en la antigüedad. $1^{o}$ Congreso Internacional, Madrid, pp. 19-46.

Bond, G., Showers, W., Cheseby, M., Lotti, R., Almasi, P., deMenocal, P., Priore, P., Cullen, H., Hajdas, I., Bonani, G. 1997. A pervasive millennial-scale cycle in north Atlantic Holocene and glacial climates. Science 278, 1257-1266. http://doi.org/10.1126/science.278.5341.1257

Burillo, F. 2007. Los Celtíberos. Etnias y estados. Barcelona, Ed. Crítica.

Certini, G., Scalenghe, R. 2011. Anthropogenic soils are the golden spikes for the Anthropocene. The Holocene 21, 1269-1274. http://doi.org/10.1177/0959683611408454

Constante, A., Dossche, R., Peña Monné, J.L., Sancho, C., de Dapper, M. 2006. Dinámica morfosedimentaria holocena en laderas y valles del escarpe de Alfocea-Juslibol (sector central de la Depresión del Ebro). In: A. Pérez Alberti, J. López Bedoya (Eds.), Geomorfología y territorio. Santiago de Compostela, pp. 979-992.

Constante, A., Dossche, R., Peña-Monné, J.L., Sancho, C., de Dapper, M. 2009. Holocene evolution and geoarchaeology in the Ebro valley around Zaragoza (Northern Spain). In: M. De Dapper, F. Vermeulen, S. Deprez, D. Taelman (Eds.), Ol'man river Geo-archaeological aspects of rivers and river plains. Academia Press, Ghent, pp. 241-256.

Constante, A., Peña-Monné, J.L. 2009. Human-induced erosion and sedimentation during the Holocene in the Central Ebro Depression, NE Spain. In: A. Romero, F. Belmonte, F. Alonso, F. López-Bermúdez (Eds.), Advances in Studies on Desertification. Universidad de Murcia, Murcia, pp. 207-210.

Constante, A., Peña-Monné, J.L., Muñoz, A. 2010. Alluvial geoarchaeology of an ephemeral stream: Implications for Holocene landscape change in the Central part of the Ebro Depression, Northeast Spain. Geoarchaeology 25 (4), 475-496. http://doi.org/10.1002/gea.20314.

Constante, A., Peña-Monné, J.L., Muñoz, A. and Picazo, J.V. 2011. Climate and anthropogenic factors affecting alluvial fan development during the late Holocene in the central Ebro Valley, northeast Spain. The Holocene 21, 275-286. https://doi.org/10.1177/0959683610378873.

Crutzen, P.J., Stoermer, E.F. 2000. The 'Anthropocene'. Global Change Newsletter 41, 17-18.

Cuadrat, J.M. 2004. El clima de Aragón. In: J.L. Peña Monné, L.A. Longares, M. Sánchez Fabre (Eds.), Geografía Física de Aragón. Aspectos generales y temáticos. Zaragoza, Institución Fernando el Católico y Univ. de Zaragoza, Zaragoza, pp.15-26.

Dearing, J.A. 2006. Climate-human-environment interactions: resolving our past. Climate Past 2, 187-203. http://doi.org/10.5194/cp-2-187-2006.

Dillehay, T.D.,Kolata,A.L.2004.Long-term human response to uncertain environmental conditions in the Andes. PNAS 101(12), 4325-4330. https://doi.org/10.1073/pnas.0400538101.

Dotterweich, M. 2008. The history of soil erosion and fluvial deposits in small catchments of central Europe: Deciphering the long-term interaction between humans and the environment - a review. Geomorphology 101, 192-208. https://doi.org/10.1016/j. geomorph.2008.05.023. 
Doughty, C.E., Wolf, A., Field, C.B. 2010. Biophysical feedbacks between the Pleistocene megafauna extinction and climate: the first human-induced global warming? Geophysical Research Letters 37, L1570. https://doi.org/10.1029/2010GL043985.

Dusar, B., Verstraeten, G., Notebaert, B., Bakker, J. 2011. Holocene environmental change and its impact on sediment dynamics in the Eastern Mediterranean. Earth-Science Reviews 108, 137-157. https://doi.org/10.1016/j.earscirev.2011.06.006.

Fernández-Turiel, J.L., Saavedra, J., Pérez-Torrado, F.J., Rodríguez-González, A., Alias, G., RodríguezFernández, D. 2012. Los depósitos de ceniza volcánica del Pleistoceno superior-Holoceno de la región de Tafí del Valle-Cafayate, Noroeste de Argentina. Geo-Temas 13, CD 07-279P, 3 pp.

Fernández-Turiel, J.L., Saavedra, J., Pérez-Torrado, F.J., Rodríguez-González, A., Carracedo, J.C., Osterrieth, M., Carrizo, J.I., Esteban, G. 2013. The largest Holocene eruption of the Central Andes found, AGU Fall Meeting, San Francisco, USA.

Foley, S.F., Gronenborn, D., Andreae, M.O., Kadereit, J.W., Esper, J., Scholz, D., Pöschl, U., Jacob, D.E., Schöne, B..R., Schreg, R., Vött, A., Jordan, D., Lelieveld, J., Weller, C.G., Alt, K.W., Gaudzinski-Windheuser, S., Bruhn, K.C., Tost, H., Sirocko, F., Crutzen, P.J. 2013. The Palaeoanthropocene - the beginnings of anthropogenic environmental change. Anthropocene 3, 83-88. http://doi.org/10.1016/j.ancene.2013.11.002.

Franco Salvi, V., Salazar, J., Berberián, E.E. 2014. Paisajes persistentes, temporalidades múltiples y dispersión aldeana en el valle de Tafí (provincia de Tucumán, Argentina). Intersecciones en Antropología 15, 307-322.

Homburg,J.A., Sandor, J.A. 2011. Anthropogenic effects on soil quality of ancient agricultural systems of the American Southwest. Catena 85(2), 144-154. https://doi.org/10.1016/j.catena.2010.08.005.

Garralla, S. 2002. Palinología del perfil El Molle, Holoceno del Valle de Tafí, Provincia de Tucumán. VIII Congreso Argentino de Paleontología y Bioestratigrafía, Argentina, pp. 1-3.

Garralla, S., Muruaga, C., Herbst, R. 2001. Lago El Rincón, Holoceno del departamento de Tafí del Valle, provincia de Tucumán (Argentina): palinología y facies sedimentarias. Publicación especial-Asociación Paleontológica Argentina, pp. 91-99.

Gutiérrez, M., Peña Monné,J.L. 1994.La Depresión del Ebro.In: M.Gutiérrez (Ed.) Geomorfología de España, Madrid, Ed. Rueda, pp. 305-349.

Kemp, R.A., Toms, P.S., Sayago, J.M., Derbyshire, E., King, M., Wagner, L. 2003. Micromorphology and OSL dating of the basal part of the loess-paleosol sequence at La Mesada in Tucumán province, Northwest Argentina. Quaternary International 106-107, 111-117. https://doi.org/10.1016/S1040-6182(02)00166-0.

Koch, P.L., Barnosky, A.D. 2006. Late Quaternary extinctions: state of the debate. Ann. Rev. Ecol. Evol. Systematics 37, 215-250. https://doi.org/10.1146/annurev.ecolsys.34.011802.132415.

Lewis, S.L., Maslin, M.A. 2015. Defining the Anthropocene. Nature 519, 171-180. https://doi. org/10.1038/nature14258.

Lightfoot, K.G., Panich, L.M., Schneider, T.D., González, S.L. 2013. European colonialism and the Anthropocene: A view from the Pacific coast of North America. Anthropocene 4, 101115. https://doi.org/10.1016/j.ancene.2013.09.002.

Martínez, J.G., Mauri, E.P., Mercuri, C., Caria, M.A., Oliszewski, N., 2013. Mid-Holocene human occupations in Tucumán (Northwest Argentina). Quaternary International 307, 86-95. https://doi.org/10.1016/j.quaint.2013.04.027.

Notebaert, B., Berger, J.-F. 2014. Quantifying the anthropogenic forcing on soil erosion during the Iron Age and Roman Period in southeastern France. Anthropocene 8, 59-69. https://doi. org/10.1016/j.ancene.2015.05.004.

Notebaert, B., Berger, J.F., Brochier, J.L. 2014. Characterization and quantification of Holocene colluvial and alluvial sediments in the Valdaine Region (southern France). Holocene 24, 1320-1335. https://doi.org/10.1177/0959683614540946. 
Ortiz, P.E., Jayat, J.P. 2007. Sigmodontinos (Rodentia: Cricetidae) del límite PleistocenoHoloceno en el valle de Tafí (Tucumán, Argentina): Taxonomía, tafonomía y significación paleoambiental. Ameghiniana 44(4), 641-660.

Peña Monné, J.L., Chueca, J., Julián, A., Echeverría, M.T. 1996. Reconstrucciones paleoambientales en el sector central de la Depresión del Ebro a partir de rellenos de valle y conos aluviales. In: A. Pérez-Alberti, P. Martini, W. Chesworth, A. Martínez-Cortizas (Eds.), Dinámica y evolución de medios cuaternarios. Xunta de Galicia, Santiago de Compostela, pp. 291-307.

Peña Monné, J.L., Echeverría, M.T., Chueca, J., Julián, A. 2000. Processus d'accumulation et d'incision pendant l'Antiquité Classique dans la vallée de la Huerva (Bassin de l'Ebre, Espagne). In: F. Vermeulen (Ed.): Geoarchaeology of the Landscapes of Classical Antiquity, Leuven, Ed. Peters, pp. 151-159.

Peña Monné, J.L., Echeverría, M.T., Petit-Maire, N., Lafont, R. 1993. Cronología e interpretación de las acumulaciones holocenas de la Val de las Lenas (Depresión del Ebro, Zaragoza). Geographicalia 30, 321-332.

Peña Monné, J.L., González, J.R., Rodríguez, J.I. 1996. Paleoambientes y evolución geomorfológica en yacimientos arqueológicos del sector oriental de la depresión del Ebro durante el Holoceno superior. In: A. Pérez-Alberti, P. Martini, W. Chesworth, A. MartínezCortizas (Eds.). Dinámica y evolución de medios cuaternarios. Xunta de Galicia, Santiago de Compostela, pp. 63-80.

Peña Monné, J.L.,Julián, A., Chueca, J.,Echeverría, M.T., Ángeles, G.R. 2004. Etapas de evolución holocena en el valle del río Huerva: Geomorfología y Geoarqueología. In: J.L. Peña Monné, L.A. Longares, M. Sánchez-Fabre (Eds.) Geografía Física de Aragón. Aspectos generales y temáticos. Universidad de Zaragoza e Institución Fernando el Católico, Zaragoza, pp. 289302. http://age.ieg.csic.es/fisica/docs/025.pdf.

Peña Monné, J.L., Pellicer, F., Julián, A., Chueca, J., Echeverría, M.T., Lozano. M.V., Sánchez, M. 2002. Mapa Geomorfológico de Aragón. Consejo de Protección de la Naturaleza de Aragón, Zaragoza.

Peña-Monné, J.L., Pérez-Lambán, F., Picazo, J., Fanlo, J. 2011. Secuencias paleoclimáticas y geoarqueología en laderas holocenas del valle del río Huerva (Depresión del Ebro). In: V. Turu, A. Constante (Eds.) El Cuaternario en España y áreas afines. Avances en 2011. XIII Reunión Nacional del Cuaternario, Andorra la Vella, pp. 217-219.

Peña-Monné, J.L., Rubio, V. y González, J.R. 2005. Aplicación de modelos geomorfológicos evolutivos al estudio de yacimientos arqueológicos en medios semiáridos (Depresión del Ebro, España). X Coloquio Ibérico de Geografía. A Geografia ibérica no cotexto europeo. Évora, 15 pp. Edición CD: http://www.apgeo.pt/files/docs/CD_X_Coloquio_Iberico_ Geografia/pdfs/076.pdf.

Peña-Monné, J.L, Rubio-Fernández, V., González-Pérez, J.R., Rodanés, J.V., Picazo, J., Medina, J., Vázquez, M.P., Sampietro-Vattuone, M.M., Pérez-Lambán, F. 2014. Geoarchaeology of defensive moats: its importance for site localization, evolution and formation process reconstruction of archaeological sites in NE Spain. Journal of Archaeological Science 50, 383-393. Doi:10.1016/j.jas.2014.07.026.

Peña Monné, J.L., Sampietro Vattuone, M.M. 2016. La secuencia paleoambiental holocena de la vertiente oriental de Loma Pelada (Valle de Tafí, Noroeste Argentino): cambios climáticos y acción humana). In: M.M. SampietroVattuone, J.L. Peña Monné (Eds.), Geoarqueología de los Valles Calchaquíes. U.N. Tucumán, Laboratorio de Geoarqueología, pp. 23-64.

Peña Monné, J.L., Sampietro Vattuone, M.M, Longares Aladrén, L.A., Pérez Lambán, J.V., Sánchez Fabre, M., Alcolea Gracia, M., Vallés, L., Echeverría, M.T., Baraza, C. 2018. Holocene alluvial sequence of Val de Zaragoza (Los Monegros) in the paleoenvironmental 
context of the Ebro Basin (Spain). Cuadernos de Investigación Geográfica 44 (1), 323-352. http://doi.org/10.18172/cig.3358.

Peña Monné, J.L., Sancho, C., Muñoz, A., Constante, A. 2014. Clima y hombre en la evolución de las vales del sector central de la Depresión del Ebro durante el Holoceno superior. In: J. Arnáez, P. González-Sampériz, T. Lasanta, B.L. Valero (Eds.), Geoecología, cambio ambiental y paisaje: Homenaje al profesor José María García Ruiz, Inst. Pirenaico de Ecología, Universidad de La Rioja, pp. 91-102.

Peña-Monné, J.L., Sancho, C., Sampietro-Vattuone, M.M., Rivelli, F., Rhodes, E.J., OsacarSoriano, M.C., Rubio-Fernández, V., García-Giménez, R. 2015. Environmental change over the last millennium recorded in the Cafayate Dune field (NW Argentina). Palaeogeography, Palaeoclimatology, Palaeoecology 438, 352-363.https://doi.org/10.1016/j. palaeo.2015.08.028.

Pérez Lambán, F. 2013. La Edad del Bronce en los cursos bajos de los ríos Huerva y Jalón. Geoarqueología y análisis espacial de los asentamientos. Unpublished $\mathrm{PhD}$ Thesis, Universidad de Zaragoza, Zaragoza.

Pérez-Lambán, F., Peña-Monné, J.L., Fanlo, J., Picazo, J.V., Badia, D., Rubio, V., GarcíaJiménez, R., Sampietro-Vattuone, M.M. 2014. Paleoenvironmental and geoarchaeological reconstruction from late Holocene slope records (Lower Huerva Valley, Ebro Basin, NE Spain). Quaternary Research 81, 1-14. https://doi.org/10.1016/j.yqres.2013.10.011.

Pérez Lambán, F., Peña-Monné, J.L., Picazo, J.V., Badia, D., Sampietro-Vattuone, M.M., González-Sámperiz, P. 2018. Buried soils and Geomorphology at La Poza gully stream (NE Spain): a geoarchaeological evolutionary model for the Mid-Late Holocene. Catena 163, 147-164. https://doi.org/10.1016/j.catena.2017.12.017.

Rasmussen, S.O., Vinther, B.M., Clausen, H.B., Andersen, K.K. 2007. Early Holocene climate oscillations recorded in three Greenland ice cores. Quaternary Science Reviews 26, $1907-$ 1914. https://doi.org/10.1016/j.quascirev.2007.06.015.

Roldán, J. 2014. Agricultura y geoquímica de suelos prehispánicos en valles Calchaquíes. Tucumán. Argentina. Tesis Doctoral, Repositorio Documental Universidad Nacional de Tucumán, Argentina. http://www .repositorio.unt.edu.ar/handle/11327/131.

Ruddiman, W.F. 2017. Geographical evidence of the Early Anthropogenic Hypothesis. Anthropocene 20, 4-14. https://doi.org/10.1016/j.ancene.2017.11.003.

Ruddiman, W.F., Ellis, E.C., Kaplan, J.O, Fuller, D.Q. 2015. Defining the epoch we live in. Is a formally designated "Anthropocene" a good idea? Science 348 (6230), 38-39. https://doi. org/10.1126/science.aaa7297.

Ruddiman, W.F., Guo, Z., Zhou, X., Wu, H., Yu, Y. 2008. Early rice farming and anomalous methane trends. Quaternary Science Reviews 27, 1291-1295. https://doi.org/10.1016/j. quascirev.2008.03.007.

Ruddiman, W.F., Thomson, J.S. 2001. The case for human causes of increased atmospheric CH4 over the last 5000 years. Quaternary Science Reviews 20, 1769-1777.https://doi.org/10.1016/ S0277-3791(01)00067-1.

Ruiz Huidobro, O.J. 1972. Descripción Geológica de la hoja 11e, Santa María, Provincias de Catamarca y Tucumán. Dirección Nacional de Minería, Boletín 134, Buenos Aires, $28 \mathrm{pp}$.

Sampietro Vattuone, M.M. 1999. Propuesta para un modelo climático del Formativo en el valle de Tafí. XIII Congreso Nacional de Arqueología, pp. 30-31.

Sampietro Vattuone, M.M. 2002. Contribución al conocimiento geoarqueológico del Valle de Tafi, Tucumán (Argentina). Tesis Doctoral. Repositorio Documental Universidad Nacional de Tucumán. Argentina, 22/02/2016, http://www.repositorio.unt.edu.ar/ handle/11327/128. 
Sampietro Vattuone, M.M. 2010. Espacio, ambiente y los inicios de la agricultura indígena en el noroeste argentino: Un enfoque geoarqueológico. Editorial JAS, Madrid, 210 pp.

Sampietro-Vattuone, M.M., Peña-Monné, J.L. 2016. Geomorphological dynamic changes during the Holocene through ephemeral stream analyses from Northwest Argentina. Catena 147, 663-677. https://doi.org/10.1016/j.catena.2016.08.029.

Sampietro Vattuone, M.M., Peña Monné, J.L., Maldonado, M.G., Sancho, C., Báez, W., Sola, A. (2018a). Registro de cambios ambientales durante el Holoceno superior en depósitos fluvioeólicos del Valle de Santa María (Noroeste Argentino). Boletín Geológico y Minero 129 (4), 647-669. https://doi.org/10.21701/bolgeomin.129.4.004.

Sampietro Vattuone, M.M., Peña-Monné, J.L., Roldán, J., Maldonado M.G., Lefebvre, M.G., Vattuone, M.A. (2018b). Human-driven geomorphological processes and soil degradation in Northwest Argentina: A geoarchaeological view. Land Degradation and Development, 29, 3852-3865. https://doi.org/10.1002/ldr.3128.

Sancho, C., Muñoz, A., Peña Monné, J.L., González, P. 2007. Evolución morfosedimentaria del sistema aluvial de Valsalada (Leciñena, Los Monegros) durante el Pleistoceno superiorHoloceno: aproximación paleoambiental. Geogaceta 41, 199-202.

Sandor, J.A., Homburg, J. A. 2017. Anthropogenic soil change in ancient traditional agricultural fields in arid to semiarid regions of the Americas. Journal of Ethnobiology 37 (2), 196-217. https://doi.org/10.2993/0278-0771-37.2.196.

Smith, B.D., Zeder, M.A. 2013. The onset of the Anthropocene. Anthropocene 4, 8-13. https://doi. org/10.1016/j.ancene.2013.05.001.

Steffen, W., Broadgate, W., Deutsch, L., Gaffney, O., Ludwig, C. 2015. The trajectory of the Anthropocene: The Great Acceleration. Anthropocene Review 2, 81-98. https://doi. org/10.1177/2053019614564785.

Steffen, W., Grinevald, J., Crutzen, P., McNeill, J. 2011. The Anthropocene: conceptual and historical perspectives. Philosophical Transactions of the Royal Society of London A369, 842-867. https://doi.org/10.1098/rsta.2010.0327.

Tovar, A., Blázquez, J.M. 1975. Historia de la Hispania Romana. La Península Ibérica desde 218 a.C. hasta el siglo V. Alianza Editorial, Madrid.

Van Zuidam, R.A. 1975. Geomorphology and Archaeology. Evidences of interrelation at historical sites in the Zaragoza region, Spain. Zeitscrift fur Geomorphologie 19, 319-328.

Waters, C.N., Zalasiewicz, J., Summerhayes, C., Barnosky, A.D., Poirier, C., Gałuszka, A., Cearreta, A., Edgeworth, M., Ellis, E.C., Ellis, M., Jeandel, C., Reinhold Leinfelder, R., McNeill, J.R., Richter, D.deB., Steffen, W., Syvitski, J., Vidas, D., Wagreich, M., Williams, M., Zhisheng, A., Grinevald, J., Odada, E., Oreskes, N., Wolfe, A. P. 2016. The Anthropocene is funcionally and stratigraphically distinct from the Holocene. Science 351 (6269). https:// doi.org/10.1126/science.aad2622.

Zalasiewicz, J., Waters, C.N., Williams, M., Barnosky, A.D., Cearreta, A., Crutzen, P., Ellis, E., Ellis, M.A., Fairchild, I.J., Grinevald, J., Haff, P.K., Hajdas, I., Leinfelder, R., McNeill, J.R., Odada, E.O., Poirier, C., Richter, D., Steffen, W., Summerhayes, C., Syvitski, J.P.M., Vidas, D., Wagreich, M., Wing, S.L., Wolfe, A.P., Zhisheng An Oreskes, N. 2015. When did the Anthropocene begin?: A mid-twentieth century boundary is stratigraphically optimal. Quaternary International 383, 196-203. https://doi.org/10.1016/j.quaint.2014.11.045. 